\title{
SMEGENŲ PAŽEIDIMO ŽYMENŲ (S100B IR NSE) KITIMAS NAUJAGIMIŲ IR KŪDIKIŲ PERIOPERACINIU LAIKOTARPIU
}

\author{
Ilona Razlevičè, Danguolė Rugytė, Andrius Macas \\ Lietuvos sveikatos moksly universiteto Medicinos akademijos Anesteziologijos klinika
}

Raktažodžiai: smegenų pažeidimo žymenys, naujagimiai, bendroji anestezija, smegenų ịsotinimas deguonimi, S100B, NSE.

\section{Santrauka}

Tikslas. Ivertinti perioperacinio laikotarpio ịtaką smegenų ląstelių pažeidimą atspindinčių baltymų S100B ir NSE koncentracijos kitimui kraujo plazmoje prieš operaciją ir po jos naujagimiams ir kūdikiams bei nustatyti šių baltymų ryši su operacijos metu stebètu smegenu įsotinimu deguonimi $\left(\mathrm{rSO}_{2} \mathrm{c}\right)$. Darbo metodika. Perspektyvusis, stebimasis, klinikinis tyrimas. Itraukti 46 naujagimiai ir kūdikiai iki 3 mèn. amžiaus, kuriems atliktos išplèstinès pilvo, dubens ar krūtinès organų operacijos. Tiriamiesiems atlikta standartinè bendrinè anestezija, taikant ịprastinę stebėseną. Smegenų įsotinimas deguonimi stebètas visos operacijos metu. S100B ir NSE žymenu koncentracijai kraujo plazmoje nustatyti buvo imamas kraujas prieš operaciją ir 24 val. po operacijos. Buvo apskaičiuotas skirtumas tarp pradinės žymens reikšmès ir 24 val. po operacijos ir išreikštas procentais nuo pradinès reikšmés (delta $\mathrm{S} 100 \mathrm{~B} \%$, delta NSE\%).

Rezultatai. Tyrimo metu buvo analizuojami 46 naujagimiai ir kūdikiai. Po 24 valandu po operacijos S100B žymuo padidejo 10 (21,7\%), NSE 11 $(23,9 \%)$ operuotu pacientų. Rasta vidutinè tiesinè koreliacija tarp abiejų tiriamų biožymenų, $\mathrm{r}=0,5$, $\mathrm{p}=0,002$, tarp delta $\mathrm{S} 100 \mathrm{~B} \%$ ir $\mathrm{rSO}_{2} \mathrm{c} \mathrm{r}=0,42$, $\mathrm{p}=0,004$, delta $\mathrm{S} 100 \mathrm{~B} \%$ ir vidurinio arterinio spaudimo (VAS) $r=-0,3, p=0,04, r S_{2} c$ koreliavo su VAS $\mathrm{r}=0,3, \mathrm{p}=0,037$. Negauta statistiškai reikšmingo ryšio tarp smegenų pažeidimo žymenų didejjimo ir nepageidaujamų neurologinių pažaidų nustatytų neurosonografijos metu.

Išvados. Pirmają parą po operacijos didžiajai daugumai pacientų reikšmingo CNS ląstelių pažeidimo ar kraujo-smegenų barjero pralaidumo padidejjimo nebuvo. Pacientams, kuriems galimai galejo būti smegenų audinio hiperoksija, stebètas S100B padidejimas. Svarbus perioperacinis faktorius, galintis turèti įtakos naujagimių ir kūdikių smegenų įsotinimui deguonimi ir smegenų pažeidimo žymenų didèjimui, yra arterinis kraujo spaudimas.

\section{Ivadas}

Atliktos retrospektyvinès studijos aprašo, kad naujagimiai, sergantys nekrotiniu enterokolitu ir patyrę chirurginị gydymą, dažniau serga cerebraliniu paralyžiumi ir turi nervų sistemos raidos sutrikimų negu gydyti konservatyviais būdais (1). Blogesnès neurologinès baigtys stebimos ir tiems vaikams, kuriems buvo atliktos igimtų širdies ydu chirurginès operacijos (2). Kiti tyrimai aprašo, kad kuo ankstesniame amžiuje kūdikis patiria anesteziją ir operaciją, tuo blogesni vèlesni mokymosi pasiekimai (3). Perioperaciniu laikotarpiu daug faktorių gali sutrikdyti smegenų kraujotaką ir sukelti nepageidaujamas neurologines baigtis: arterinio kraujo spaudimo svyravimai, anglies dvideginio $\left(\mathrm{CO}_{2}\right)$ kiekio pokyčiai, įkvepiamo $\mathrm{O}_{2}$ koncentracija, gliukozès kiekis kraujyje, temperatūros svyravimai (1). Neurologini pažeidimą taip pat gali sąlygoti: nepakankamas smegenų subrendimas, užtrukusi smegenų hipoksija, nepakankama smegenų kraujotaka dirbtinès apytakos sąlygomis, sedacija ir kt. (4). Specifiniai serumo biocheminiai žymenys smegenų ląstelių pažeidimui nustatyti padètų išvengti galimų komplikacijų ir užtikrintų savalaikio gydymo taktiką (5). Labiausiai ištirti naujagimiams, vaikams ir suaugusiems smegenų ląstelių pažeidimo žymenys yra NSE (neuronams specifinè enolazė) ir S100B, tačiau jie nebuvo tirti naujagimiams ir kūdikiams perioperaciniu laikotarpiu ne širdies operacijų metu (4). Šie baltymai atsiranda plazmoje, esant smegenų ląsteliu ar kraujo-smegenų barjero pažeidimui. NSE - glikolitinis citoplazmos fermentas, esantis neuronuose, daugiausia pilkojoje centrinès nervu sistemos (CNS) medžiagoje, neuroendokrininèse ir navikinèse ląstelèse. Itvykus ląstelès destrukcijai šis baltymas pasyviai pereina ị ekstraceliulinị tarpą. Jo biologinis 
gyvavimo pusperiodis 48 val. (6). S100B - rūgštinis $\mathrm{Ca}^{2+}$ surišantis proteinas, didžiausiais kiekiais aptinkamas CNS: astrocituose, Švano ląstelèse, baltojoje CNS medžiagoje. Pažeidus nervinio audinio struktūrą S100B pereina ị cerebrospinalinį skystị ir difunduoja pro kraujo-smegenų barjerą į sisteminę kraujotaką. Po smegenų pažeidimo S100B išsiskyrimas stebimas apie 4 paras (6). S100B unikalus ir tuo, kad kol kas tai vienintelis iš žymenų, kuris buvo susietas su anestetikų sukelta smegenų ląstelių apoptoze gyvūnams (7). Artimosios infraraudonosios spektroskopijos, skirtos naujagimių galvos smegenų įsotinimui deguonimi $\left(\mathrm{rSO}_{2} \mathrm{c}\right)$ vertinti, parametrai patikimai koreliuoja su S100B koncentracija šlapime tiriant išnešiotus ir neišnešiotus naujagimius per pirmąsias 6 gyvenimo valandas (8).

Darbo tikslas - įvertinti perioperacinio laikotarpio įta-

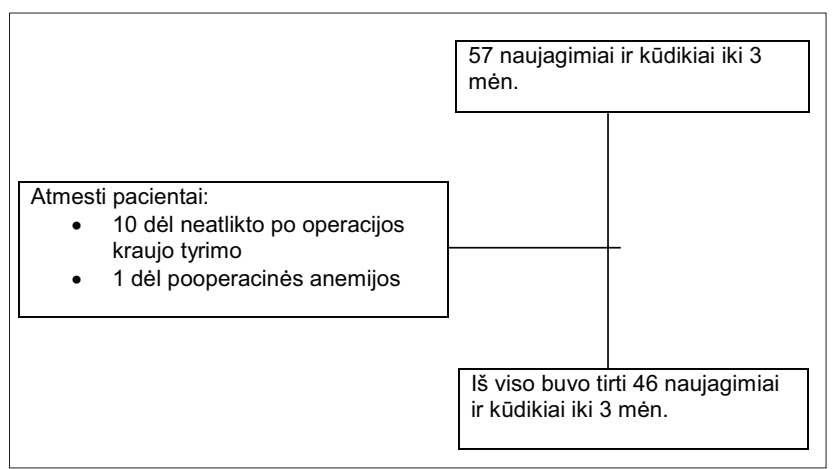

1 pav. Pacientų įtraukimo ị tyrimą diagrama

1 lentelè. Demografiniai ir klinikiniai pacientų duomenys. Nurodyta duomenų mediana, minimali ir maksimali reikšmès arba proporcija (n $(\%)$

\begin{tabular}{|l|c|}
\hline Požymis & $\begin{array}{c}\text { Iš viso } \\
(\boldsymbol{n}=\mathbf{4 6})\end{array}$ \\
\hline Amžius (dienos) & $10,5(0-90)$ \\
Naujagimiai (n(\%) & $37(80,4)$ \\
Kūdikiai (n(\%)) & $9(19,6)$ \\
\hline Gestacinis amžius (savaitès) & $38(30-42)$ \\
Išnešioti (n(\%) & $30(65,2)$ \\
Neišnešioti (n(\%) & $16(34,8)$ \\
\hline Svoris (g) & $3398(1340-6300)$ \\
\hline Lytis & \\
Berniukai (n(\%) & $26(56,5)$ \\
Mergaitès (n(\%) & $20(43,5)$ \\
\hline Operacijos pobūdis: & $2(4,3)$ \\
Krūtinės ląstos (n(\%) $\%)$ & $30(65,2)$ \\
Pilvo (n(\%) & $6(13)$ \\
Urologinės (n(\%) & $8(17,4)$ \\
Kitos (n(\%) & $42(91,3) / 4(8,7)$ \\
Kelinta operacija (pirma/pakartotina) & $80(30-260)$ \\
\hline Anestezijos trukmė (min)
\end{tabular}

ką smegenų ląstelių pažeidimą atspindinčių baltymų S100B ir NSE koncentracijos kitimui kraujo plazmoje prieš operaciją ir po jos naujagimiams ir kūdikiams bei nustatyti šių baltymų ryšį su operacijos metu stebetu smegenų įsotinimu deguonimi.

\section{Tyrimo medžiaga ir metodai}

Perspektyvusis, stebimasis, klinikinis tyrimas atliktas

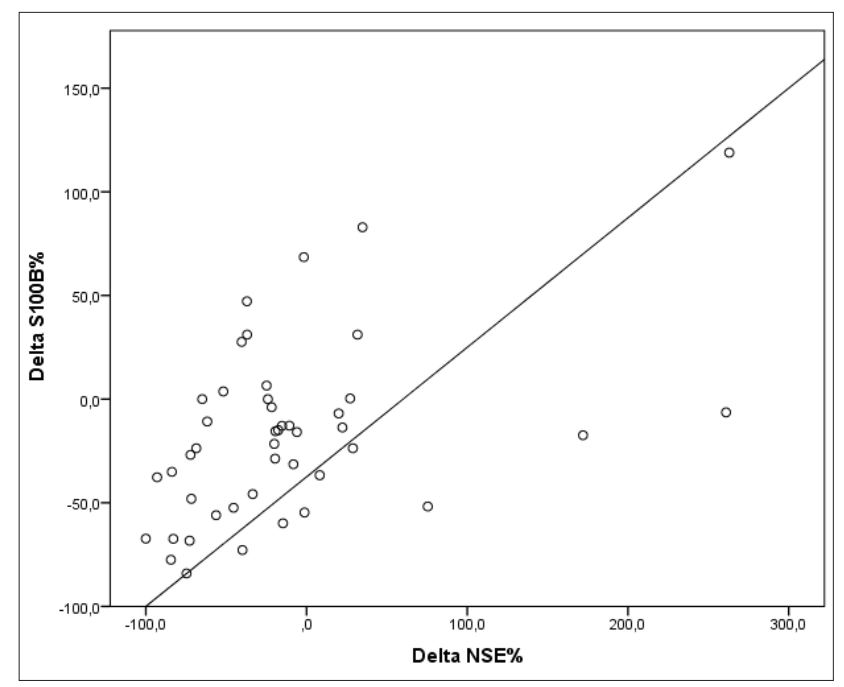

2 pav. Koreliacija tarp delta S100B\% ir delta NSE\% (Spearmen'o koreliacijos koeficientas, $\mathrm{r}=0,5, \mathrm{p}=0,002$ ).

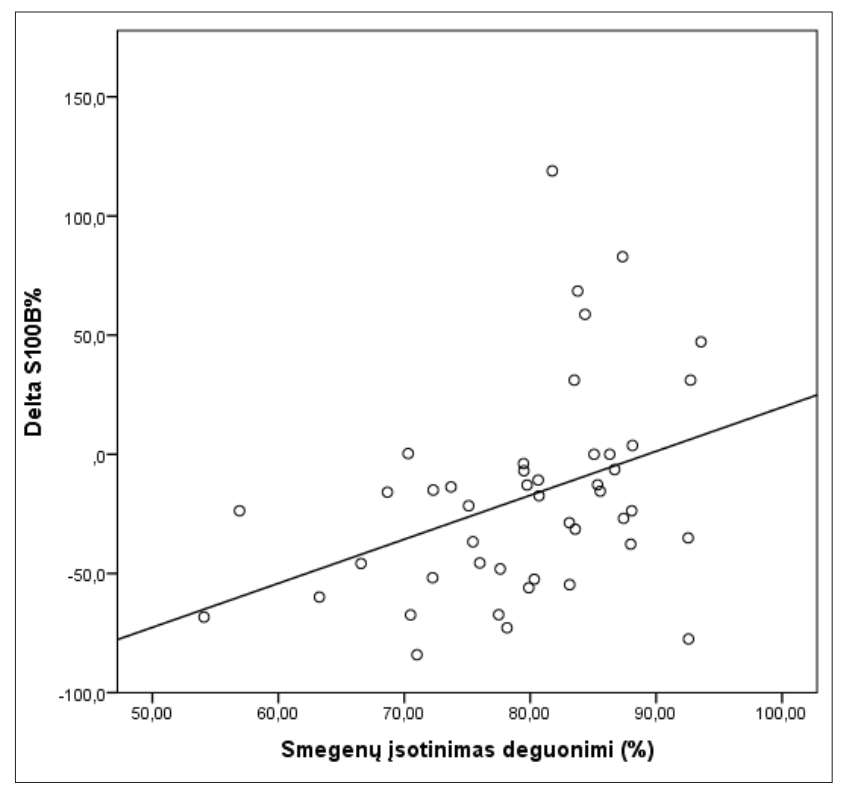

3 pav. Koreliacija tarp delta $\mathrm{S} 100 \mathrm{~B} \%$ ir smegenų įsotinimo deguonimi (\%), (Spearmen'o koreliacijos koeficientas, $\mathrm{r}=0,42$, $\mathrm{p}=0,004)$. 
Lietuvos sveikatos mokslu universiteto Medicinos akademijos Anesteziologijos klinikoje. Kauno regioninis bioł medicininių tyrimų etikos komitetas patvirtino protokolą ir išdave leidimą Nr. BE-2-43. Tyrimas atliktas 2013 2015 metais. I tyrimą įtraukti naujagimiai ir kūdikiai iki 3 mèn. amžiaus, kuriems atliktos išplèstinès pilvo, dubens ar krūtinès organų operacijos (laparotomijos, torakotomijos, sternotomijos, lumbotomijos) ir kurių tèvai davè raštišką sutikimą dalyvauti tyrime.

I tyrimą neįtraukti naujagimiai ir kūdikiai operuojami dèl auglių, kuriems diagnozuotas sepsis, anemija, sergantys kaulų-raumenų ligomis bei operuojami dèl širdies ir kraujagyslių bei neurologinès -patologijos. Detali pacientu ịtraukimo ị tyrimą diagrama pavaizduota 1 paveiksle.

I tyrimą ịtraukti 57 pacientai, 11 pacientu vèliau buvo atmesti, tad iš viso buvo tirti 46 naujagimiai ir kūdikiai.

Tiriamiesiems atlikta standartinè bendrinè anestezija, taikant ịprastinę stebėseną: neinvazinị arterinị kraujo spaudimą (AKS), širdies susitraukimų dažnị (ŠSD), hemoglobino įsotinimą deguonimi - pulsinę oksimetriją $\left(\mathrm{SpO}_{2}\right)$, elektrokardiogramą $(\mathrm{EKG})$, temperatūrą $\left(\mathrm{T}^{\circ}\right)$. $\mathrm{SpO}_{2}$ palaikytas $\geq 90 \%$ neišnešiotiems naujagimiams ir $\geq 94 \%$ išnešiotiems naujagimiams ir kūdikiams. Šios ribos rekomenduotinos dèl mažesnès nekrotizuojančio enterokolito rizikos ir geresnio naujagimių išgyvenamumo (9). Tiksliam AKS matavimui buvo parinkta manžetè, dengianti du trečdalius žasto, ir matavimas atliekamas kas 5 min. Visiems pacientams atlikta bendriné nejautra su trachejos intubacija ir

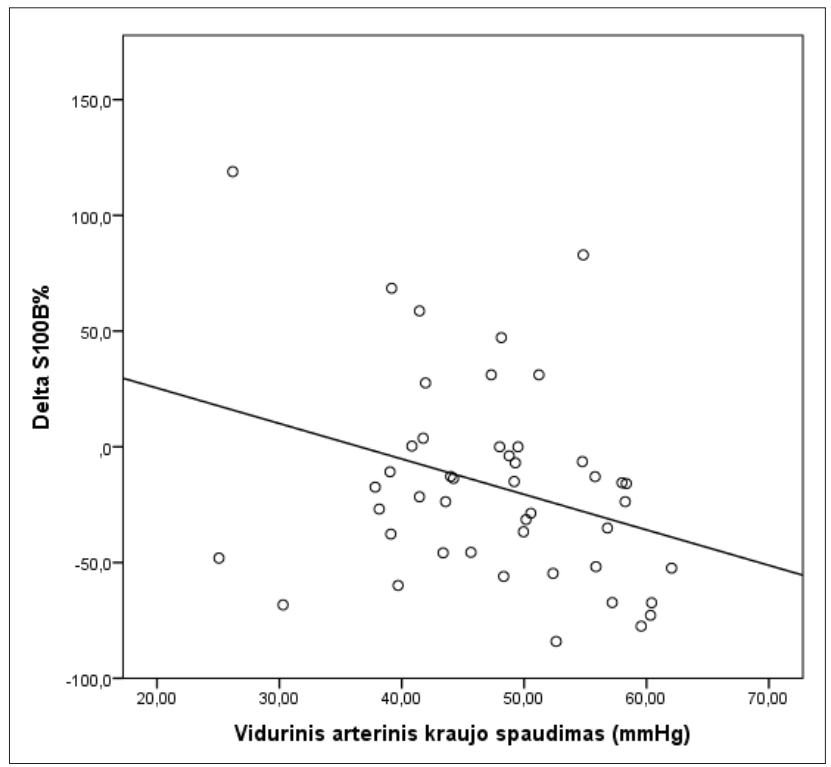

4 pav. Koreliacija tarp delta $\mathrm{S} 100 \mathrm{~B} \%$ ir vidurinio arterinio kraujo spaudimo (VAS), (Spearmen'o koreliacijos koeficientas, $\mathrm{r}=-0,3$, $\mathrm{p}=0,04)$. dirbtine plaučių ventiliacija. Anestezijos indukcija atlikta tiekiant deguonies, oro ir sevoflurano mišini per veido kaukę, vèliau skirti raumenų relaksantai ir fentanilis $1 \mu \mathrm{g} / \mathrm{kg}$ i veną. Anestezijos metu slègis kvejpavimo takuose neviršijo $15 \mathrm{mmHg}$ ir anglies dvideginio kiekis iškvèpime $\left(\mathrm{EtCO}_{2}\right)$ buvo palaikomas 35-45 mmHg. ŠSD ir AKS buvo palaikomi $20 \%$ ribose nuo pradinio matavimo. Analgezijai palaikyti buvo skiriamas fentanilis $1 \mu \mathrm{g} / \mathrm{kg}$ pagal reikalą, taip pat pagal reikalą skirti raumenų relaksantai. Infuzoterapija kristaloidais taikyta $6-10 \mathrm{ml} / \mathrm{kg} / \mathrm{val}$. Papildoma infuzinè terapija buvo skiriama atsižvelgiant į AKS, ŠSD pokyčius, operacijos eigą. Normotermija operacijos metu palaikyta šildomais čiužiniais ir šildančiomis lempomis.

Smegenų įsotinimo deguonimi stebejjimui operacijos metu kaktos srityje buvo klijuojami du lipnūs elektrodai. Duomenys registruoti INVOS SYSTEM aparatu nepertraukiamai visą operaciją iki operacinio pjūvio užsiuvimo. Po operacijos pacientai buvo neekstubuoti ir perkelti tolesniam gydymui ị intensyviosios terapijos skyrių.

S100B ir NSE žymenų koncentracijai kraujo plazmoje nustatyti buvo imamas kraujas prieš operaciją ir 24 val. po operacijos. Žymenys nustatyti ELISA (enzym-linked immunosorbent assay) metodu (Bio Vendor Human S100B ELISA ir CanAg NSE EIA). Reagentų rinkinys biožymenų nustatymui buvo tiekiamas to paties gamintojo, tačiau su ilgais laiko tarpais, todèl siekiant išvengti netikslumų buvo apskaičiuotas skirtumas tarp pradinės žymens reikšmės ir 24 val. po operacijos ir išreikštas procentais nuo pradinès reikšmès (delta S100B\%, delta NSE\%).

Statistiné duomenų analizé atlikta naudojant IBM SPSS statistics 20 programini paketą. Taikant KolmogorovoSmirnovo testą, nustatyta, kad kintamieji netenkino pasiskirstymo normališkumo sąlygos, todèl tolesniems skaičiavimams taikyti neparametriniai analizès metodai. Kiekybiniai kintamieji aprašyti paskaičiavus medianą, minimalią ir maksimalią reikšmes. Kiekybinių duomenų palyginimui tarp grupių taikytas Mann-Whitney U kriterijus. Kokybinių požymių vertinimui grupése taikytas chi kvadrato kriterijus $\left(\chi^{2}\right)$. Siekiant nustatyti, ar buvo ryšys tarp delta $\mathrm{S} 100 \mathrm{~B} \%$, delta NSE\% ir perioperacinių veiksnių apskaičiuotas Spearmen'o koreliacijos koeficientas. Duomenys statistiškai patikimai skyrèsi, kai reikšmingumo lygmuo $\mathrm{p}$ buvo mažiau nei 0,05 .

\section{Rezultatai}

Tyrimo metu buvo analizuojami 46 pacientai, iš kuriu $30(65,2 \%)$ buvo išnešiotų ir $16(34,8 \%)$ neišnešiotų naujagimių ir kūdikių. Demografiniai ir klinikiniai požymiai parodyti 1 lenteleje.

Po 24 valandų po operacijos S100B žymuo padidèjo 10 
(21,7\%), NSE $11(23,9 \%)$ operuotų naujagimių ir kūdikių. Rasta vidutiné tiesinè koreliacija tarp abiejų tiriamų biožymenų, $\mathrm{r}=0,5, \mathrm{p}=0,002$ ( 2 pav.).

Rasta koreliacija tarp delta $\mathrm{S} 100 \mathrm{~B} \%$ ir $\mathrm{rSO}_{2} \mathrm{c} \mathrm{r}=0,42$, $\mathrm{p}=0,004$ (3 pav.), tarp delta $\mathrm{S} 100 \mathrm{~B} \%$ ir vidurinio arterinio spaudimo (VAS) $\mathrm{r}=-0,3, \mathrm{p}=0,04$ (4 pav.), $\mathrm{rSO}_{2} \mathrm{c}$ koreliavo su VAS $r=0,3, p=0,037$.

Naujagimiai buvo palyginti tarp grupių, kuriems didèjo smegenų pažeidimo žymenys ir ne. Nei pagal anestetikų, nei seduojančių medžiagų kiekị naujagimių grupès nesiskyrè. Didžioji dalis pacientų $(91,3 \%)$ patyrẻ vieną operaciją ir skirtumo tarp smegenų pažeidimo žymenų kitimo ir operacijos skaičiaus bei anestezijos trukmès nebuvo. Negauta statistiškai reikšmingo ryšio tarp smegenų pažeidimo žymenų didejjimo ir nepageidaujamų neurologinių pažaidų, nustatytu neurosonografijos metu (subependiminès, intraskilvelinès kraujosruvos).

\section{Tyrimo rezultatų aptarimas}

Sveikų suaugusių žmonių organizme aptinkamas NSE kiekis yra labai mažas, o S100B koncentracija kraujo plazmoje neišmatuojama. NSE padidejimas nustatomas pacientams, turintiems piktybinių neuroendokrininių navikų, smulkiụjų ląstelių plaučių karcinomos, neuroblastomos atvejais, o ištikus išeminiam ar hemoraginiam insultui, CNS traumai padideja ir NSE ir S100B (10). Atliktuose tyrimuose aprašoma, kad aukščiausia S100B koncentracija aptinkama naujagimių kraujyje ir vèliau mažèja iki neišmatuojamos (11). Atsakymo dar nèra, kodèl S100B randamas naujagimiams be aiškių CNS pažeidimų. Manoma, kad naujagimių kraujo-smegenų barjeras yra mažiau selektyvus ir yra didesnè baltymų kaita nervų ląstelèse dèl sparčiai bręstančios CNS (12), taip pat mažesnis išsiskyrimas per inkstus (13). Suaugusiems pacientams perioperaciniu periodu, kuriems nèra pastebimų CNS pažeidimų, S100B padidejjimas aiškinamas subklinikiniais smegenų ląstelių pakenkimais, kurių metu vyksta grižtami pokyčiai (difuziné mikroembolizacija ir padideję̨s kraujo-smegenų barjero pralaidumas) (4). Tiriant intensyviosios terapijos skyriuose gydomus naujagimius, nustatyta, kad pacientų būklès sunkumas patikimai koreliuoja su didesnemis S100B ir NSE koncentracijomis $(6,14)$. Didžiausi šių žymenų kiekiai nustatyti po invazyvių, didelès apimties operacijų, pavyzdžiui, ịgimtų širdies defektų korekcijos, organų transplantacijos (14).

Visi bendrieji anestetikai sukelia širdies ir kraujagyslių sistemos slopinimą, dèl to smegenu kraujotaka ir oksigenacija gali būti nepakankama. Egzistuoja ir kiti faktoriai, galintys paveikti naujagimių ir kūdikių smegenų aprūpinimą deguonimi ir normalią jų funkciją (kvėpavimo funkci- jos sutrikimai, medžiagų apykaitos sutrikimai, hiperoksija, ypač neišnešiotiems naujagimiams ir kt.) (1). Atliktas tyrimas atskleidė reikšmingą koreliaciją tarp smegenų ịsotinimo deguonimi ir smegenų ląstelių pakenkimo žymens delta S100B\%. Tiriant sunkiai sergančius vaikus iki 18 metų, kurie buvo gydomi intensyviosios terapijos skyriuje, rasta neigiama koreliacija tarp S100B ir smegenų isotinimo deguonimi, tačiau ịrodymų apie minètų tyrimų diagnostinę vertę nuspèjant neurologinę būklę dar trūksta (15). Tyrimai su gyvūnais parodè, $\mathrm{kad} \mathrm{rSO}_{2} \mathrm{c}$ ir S100B yra: priklausomi nuo amžiaus, koreliuoja su hemodinaminiais svyravimais, kurių metu didejja hematoencefalinio barjero pralaidumas, kuris gali būti tiek dèl fiziologinio CNS vystymosi, tiek dèl smegenų pakenkimo $(16,12)$. Nemoto su kolegomis aprašè, kad suaugusiems pacientams, patyrusiems galvos smegenų insultą, buvo stebètos aukštesnès $\mathrm{rSO}_{2} \mathrm{c}$ reikšmès pažeistose galvos smegenų srityse, kas reikštų, kad pažeisti arba mirę neuronai suvartoja mažiau arba visai nevartoja deguonies (17). Tiriant besivystančių gyvūnų smegenis dèl smegenų pažeidimo ir neuronų mirties taip pat stebètas mažesnis deguonies suvartojimas pirmąsias 24-78 val. (18). Panašūs radiniai aprašomi ir naujagimiams, gimusiems asfiksijoje ir patyrusiems nepageidaujamas neurologines baigtis (16, 19). Mes stebejome S100B padidejjimą 7 pacientams, kuriems smegenų ísotinimas deguonimi buvo per $85 \%$ (3 pav.). Net trumpas hiperoksijos periodas naujagimiams sukelia nepageidaujamas ilgalaikes pasekmes, sustiprina galvos smegenų išemiją, lydimą neuronų apoptozès. Naujagimiams ir kūdikiams širdies ir kraujagyslių operacijų metu deguonies koncentracija tiekiama atsižvelgiant ị artimosios infraraudonosios spektroskopijos parodymų rezultatus, siekiant išvengti hiperoksijos sukeltos vazokonstrikcijos (20). Kadangi atokiųjų neurologinio vystymosi baigčių netyrème, nežinome, ar mūsų tyrimo metu rastą koreliaciją tarp $\mathrm{rSO}_{2} \mathrm{c}$ ir smegenų biožymenų didejjimo galime paaiškinti sumažèjusiu deguonies metabolizmu smegenų ląstelèse ir galimu ląstelių pažeidimu. Žymenų padidejjimo susiejimas su neurologine ligonių būkle padètų atsakyti ị klausimą, ar žymenų tyrimas yra naudingas stebejjimo būdas.

Normalaus arterinio kraujo spaudimo ribos naujagimiams vis dar išlieka diskusijų objektu. Aprašoma saugi apatinè vidurinio arterinio kraujo spaudimo riba yra ne žemesné negu amžius pagal gestacines naujagimio savaites ir ne žemesnè negu $30 \mathrm{mmHg}$ net neišnešiotiems naujagimiams. Atlikti keli tyrimai, kuriuose pateikiami duomenys apie blogesnes naujagimių neurologines baigtis, kuriems buvo stebėtas mažesnis arterinis kraujo spaudimas (21). Tiriant vaikus iki 12 metų, vėlyvuoju pooperaciniu laikotarpiu, kuriems atlikta širdies ir kraujagyslių operacija, buvo pastebèta, kad po operacijos išsivysčiusi hipotenzija 
stipriai koreliavo su S100B (11). Sepsinio šoko metu vaikų kraujyje buvo rasta ir S100B ir NSE žymenų kiekio padidejjimas (22). Svarbu įsidèmèti, kad ne tik anestetikai, bet ir kiti perioperaciniai veiksniai gali pažeisti smegenų ląsteles ir sukelti blogas neurologines baigtis (11). Mūsų atliktame tyrime gavome tiesioginę koreliaciją tarp VAS ir $\mathrm{rSO}_{2} \mathrm{c}$ bei atvirkštinę koreliaciją tarp VAS ir delta S100B\%. Gauti rezultatai parodo, kad esant hipotenzijai galimai smegenu kraujotaka vyksta pasyviai dèl sutrikdytos autoreguliacijos galvos smegenyse, ypač neišnešiotiems naujagimiams.

Keletas tyrimu aprašo slopinanti propofolio ir sevoflurano poveikį sveikų suaugusių pacientų smegenų kraujotakai, tačiau duomenų apie naujagimių populiaciją nèra pateikta (23). Mūsų atliktame tyrime nepastebejome jokios koreliacijos tarp smegenų pažeidimo žymenų padidejimo ir vartotų anestetikų koncentracijos iki 24 val. po operacijos.

\section{Išvados}

Pirmają parą po operacijos didžiajai daugumai pacientų reikšmingo CNS ląstelių pažeidimo ar kraujo-smegenų barjero pralaidumo padidèjimo, kuris būtų susijęs su smegenų pažeidimo žymenų koncentracijos padidejjimu po operacijos, nebuvo. Pacientams, kuriems galimai galèjo būti smegenų audinio hiperoksija, stebètas S100B padidèjimas. Tik tolesni tyrimai padès išaiškinti hiperoksijos įtaką smegenų kraujotakai ir įsotinimui deguonimi. Svarbus perioperacinis faktorius, galintis turèti itakos naujagimiu ir kūdikių smegenų įsotinimui deguonimi ir smegenų pažeidimo žymenų didejjimui, yra arterinis kraujo spaudimas. Žymenų pokyčio susiejimas su neurologine ligonių būkle padètų atsakyti ị klausimą, ar žymenų tyrimas yra naudingas stebejjimo būdas.

\section{Literatūra}

1. McCann ME, Soriano SG. Perioperative central nervous system injury in neonates. Br J Anaesth 2012; 109 (S1):i60-i67.

http://dx.doi.org/10.1093/bja/aes424

2. Wise-Faberowski L, Loepke A. Anesthesia during surgical repair for congenital heart disease and developing brain: neurotoxic or neuroprotective? Pediatr Anest 2011; 21:554-559. http://dx.doi.org/10.1111/j.1460-9592.2011.03586.x

3. Block RI, Thomas JJ, Bayman EO, Choi JY, Kimble KK, Todd $\mathrm{MM}$. Are anesthesia and surgery during infancy associated with altered academic performance during childhood? Anesthesiology 2012; 117:494-503.

http://dx.doi.org/10.1097/ALN.0b013e3182644684

4. Liu Y, Xu Y, Li DZ, Shi Y, Ye M. Comparison of S100B and NSE between cardiac surgery and interventional therapy for children. Pediatr Cardiol 2009;30(7):893-7.

http://dx.doi.org/10.1007/s00246-009-9454-x
5. Šuškevičienė I., Nekrašienė M., Rugyte D.Č., Vilkẻ A., Bukauskas T., Bilskienė D., Macas A. Naujagimių ir kūdikių smegenų ląstelių apoptozė ir perioperacinis periodas: ar yra ryšys? Sveikatos mokslai, 2013;1:133-137.

6. Vos PE, Verbeek MM. Brain specific proteins in serum: do they reliably reflect brain damage? Shock 2002;18(5):481-482.

http://dx.doi.org/10.1097/00024382-200211000-00017

7. Wang S, Peretich K, Zhao Y, Liang G, Meng Q, Wei H. Anesthesia-induced neurodegeneration in fetal rat brains. Pediatr Res 2009 Oct;66(4):435-40.

http://dx.doi.org/10.1203/PDR.0b013e3181b3381b

8. Tina LG, Frigiola A, Abella R, Artale B, Puleo G, D'Angelo S, Musmarra C, Tagliabue P, Li Volti G, Florio P, Gazzolo D. Near Infrared Spectroscopy in Healthy Preterm and Term Newborns: Correlation with Gestational Age and Standard Monitoring Parameters. Curr Neurovasc Res 2009;6:148-54.

http://dx.doi.org/10.2174/156720209788970090

9. Neumann RP, von Ungern-Sternberg BS. The neonatal lungphysiology and ventilation. Pediatr Anesth 2014;24(1):10-21. http://dx.doi.org/10.1111/pan.12280

10. Bonacchi M, Prifti E, Maiani M, Bartolozzi F, Di Eusanio M, Leacche M. Does-off pump coronary revascularization reduce the release of the cerebral markers, S-100beta and NSE? Heart Lung Circ 2006;12:314-319.

http://dx.doi.org/10.1016/j.hlc.2006.05.007

11. Lardner D, Davidson A, McKenzie I, Cochrane A. Delayed rises in serum S100B levels and adverse neurological outcome in infants and children undergoing cardiopulmonary bypass. Paediatr Anaesth 2004;14:495-500.

http://dx.doi.org/10.1111/j.1460-9592.2004.01230.x

12. Micheti F, Gazzolo D. S100B protein in biological fluids: a tool in perinatal medicine. Clin Chem 2002; 48:2097-104.

13. Spinella PC, Dominguez T, Drott HR, Huh J, McCormick L, Rajendra A, Argon J, McIntosh T, Helfaer M. S-100 beta protein serum levels in healthy children and its association with outcome in pediatric traumatic brain injury. Crit Care Med 2003;31:939-945.

http://dx.doi.org/10.1097/01.CCM.0000053644.16336.52

14. Vanhorebeek I, Gielen M. Glucose dysregulation and neurological injury biomarkers in critically ill children. J Clin Endocrinol Metab 2010;95(10):4669-79.

http://dx.doi.org/10.1210/jc.2010-0805

15. Subbaswamy A, Hsu AA, Weinstein S, Bell MJ. Correlation of cerebral near-infrared spectroscopy (cnirs) and neurological markers in critically ill children. Neurocrit Care 2009;10:129135. http://dx.doi.org/10.1007/s12028-008-9122-7

16. Toet MC, Lemmers PM, van Schelven LJ, van Bel F. Cerebral oxygenation and electrical activity after birth asphyxia: their relation to outcome. Pediatrics 2006; 117:333-339.

http://dx.doi.org/10.1542/peds.2005-0987 
17. Nemoto E, Yonas H, Kassam A. Clinical experience with cerebral oximetry in stroke and cardiac arrest. Crit Care Med 2000;28:1052-1054.

http://dx.doi.org/10.1097/00003246-200004000-00023

18. Peeters-Scholte C, Koster J, Veldhuis W, van den Tweel E, Zhu C, Kops N, Blomgren K, Bar D, van Buul-Offers S, Hagberg H, Nicolay K, van Bel F, Groenendaal F. Neuroprotection by selective nitric oxide synthase inhibition at 24 hours after perinatal hypoxia-ischemia. Stroke 2002;33:2304-2310.

http://dx.doi.org/10.1161/01.STR.0000028343.25901.09

19. Cady EB, Amess PN, Penrice J, Wylezinska M, Sams V, Wyatt JS. Early cerebral-metabolite quantification in perinatal hypoxicischaemic encephalopathy by proton and phosphorus magnetic resonance spectroscopy. Magn Reson Imaging 1997; 15:605-611.

http://dx.doi.org/10.1016/S0730-725X(97)00017-9

20. Habre W, Petak F. Perioperative use of oxygen: variabilities across age. Br J Anaesth 2014;113 (S2):ii26-ii36.

http://dx.doi.org/10.1093/bja/aeu380

21. Cerbo RM, Cabano R, Di Comite A, Longo S, Maragliano R, Stronati M. Cerebral and somatic rSO2 in sick preterm infants. J Matern Fetal Neonatal Med 2012; 25(S4):97-100.

22. Hsu AA, Fenton K, Weinstein S, et al. Neurological injury markers in children with septic shock. Pediatr Crit Care 2008;9:24551.

http://dx.doi.org/10.1097/PCC.0b013e3181727b22

23. Vutskits L. Cerebral blood flow in the neonate. Pediatr Anesth 2014;24:22-29.

http://dx.doi.org/10.1111/pan.12307

\section{CHANGES OF BRAIN INJURY MARKES (S100B AND NSE) IN NEWBORNS AND INFANTS PERIOPERATIVE PERIOD}

I. Razlevičè, D. Rugytė, A. Macas

Key words: brain injury markers, neonates, general anesthesia, cerebral oxygenation, S100B, NSE.
Summary

The aim of our study was to evaluate the influence of perioperative period (first 24 hours) on brain specific proteins S100B and NSE concentration in plasma and to correlate it with intraoperative cerebral oxygen saturation $\left(\mathrm{rSO}_{2} \mathrm{c}\right)$ in neonates and infants, Methods: The prospective observational clinical study included 46 newborns and infants younger than 3 months. All patients required elective or urgent abdominal, urological, thoracic or other major general surgery. After arrival to the OR, standard monitoring was started before anesthesia. All patients underwent general anesthesia with tracheal intubation and controlled ventilation. Monitoring of regional cerebral saturation of oxygen was started before anesthesia and data were captured throughout the surgery. Blood samples for plasma S100B and NSE analysis were collected before surgery and $24 \mathrm{~h}$ after the operation. The difference between markers initial (before anesthesia) values and $24 \mathrm{~h}$ after operation was calculated and expressed as a percent of the initial value (delta S100B\%, delta NSE\%). Results: 46 patients were enrolled in this study. 24 $\mathrm{h}$ after operation we found that S100B increased in $10(21.7 \%)$ and NSE in $11(23.9 \%)$ neonates. Delta NSE and delta S100B well correlated $\mathrm{r}=0.5, \mathrm{p}=0.002$. Delta $\mathrm{S} 100 \mathrm{~B} \%$ correlated with $\mathrm{rSO}_{2} \mathrm{c}$ $\mathrm{r}=0.42, \mathrm{p}=0.004$ and with mean arterial pressure (MAP) $\mathrm{r}=-0.3$, $\mathrm{p}=0.04$. The correlation was also observed between $\mathrm{rSO}_{2} \mathrm{c}$ and MAP $\mathrm{r}=0.3, \mathrm{p}=0.037$. We did not find statistically significant relationship between the brain specific markers and abnormal neurosonography. In conclusion, $24 \mathrm{~h}$ after operation for the vast majority of patients brain cell damage or increased brain blood barrier permeability, which could result in increased concentration of brain specific proteins, did not occur. However, increased $\mathrm{S} 100 \mathrm{~B}$ values were observed in infants with presumable brain hyperoxia $\left(\mathrm{rSO}_{2} \mathrm{c}>85 \%\right)$. Diminished arterial blood pressure may affect newborns and infants cerebral oxygenation and cause higher release of brain cell damage proteins perioperatively.

Correspondence to: ilonos_pastas@yahoo.com

Gauta 2016-06-19 